\title{
From a law for greed to a law for need: the underlying importance of prof. Sornarajah's paper
}

In response to the paper by $M$. Sornarajah, "A law for need or a law for greed: restoring the lost law in the international law of foreign investment" (see pp. 329-357)

\section{Howard Mann}

Published online: 21 March 2008

(C) Springer Science+Business Media B.V. 2008

\section{Erratum to: Int Environ Agreements DOI: 10.1007/s10784-006-9024-0}

This erratum is initiated in order to correct the authors name which appeared in the article 10.1007/s10784-006-9024-0.

Prof. M. Sornarajah's name is to be read as M. Sornarajah instead of M. Sornorajah as previously indicated

The online version of the original article can be found at http://dx.doi.10.1007/s10784-006-9024-0

H. Mann $(\bowtie)$

International Institute for Sustainable Development, 424 Hamilton Ave S.,

Ottawa, Ont., Canada K1Y 1E3

e-mail: h.mann@sympatico.ca 